NBER WORKING PAPER SERIES

\author{
PERCEPTIONS OF ECONOMIC \\ INSECURITY: EVIDENCE FROM \\ THE SURVEY OF ECONOMIC \\ EXPECTATIONS
}

Jeff Dominitz

Charles F. Manski

NBER Working Paper 5690

\author{
NATIONAL BUREAU OF ECONOMIC RESEARCH \\ 1050 Massachusetts Avenue \\ Cambridge, MA 02138 \\ July 1996
}

This research is supported by grant SBR-9223220 from the National Science Foundation and by grant 91ASPE236A from the Office of the Assistant Secretary for Planning and Evaluation, U.S. Department of Health and Human Services. We are grateful to Bob Lee and Jim Sweet for enabling collection of the data by the College of Letters and Science Survey Center at the University of Wisconsin-Madison. This paper is part of NBER's research program in Labor Studies. Any opinions expressed are those of the authors and not those of the National Bureau of Economic Research.

(C) 1996 by Jeff Dominitz and Charles F. Manski. All rights reserved. Short sections of text, not to exceed two paragraphs, may be quoted without explicit permission provided that full credit, including $(\mathcal{O}$ notice, is given to the source. 


\title{
PERCEPTIONS OF ECONOMIC \\ INSECURITY: EVIDENCE FROM \\ THE SURVEY OF ECONOMIC \\ EXPECTATIONS
}

\begin{abstract}
We have recently initiated the Survey of Economic Expectations (SEE) in an effort to learn how Americans perceive their near-term futures. This paper uses SEE data on over two thousand labor force participants interviewed in 1994 and 1995 to describe how Americans in the labor force perceive the risk of near-term economic misfortune. We measure economic insecurity through responses to questions eliciting subjective probabilities of three events in the year ahead: absence of health insurance, victimization by burglary, and job loss. With item response rates exceeding 98 percent, respondents clearly are willing to answer the expectations questions and they appear to do so in a meaningful way. Using the responses to classify individuals as relatively secure, relatively insecure, and highly insecure, we find that respondents with a high risk of one adverse outcome tend also to perceive high risks of the other outcomes. Economic insecurity tends to decline with age and with schooling. Black respondents perceive much greater insecurity than do whites, especially among males. Within the period 1994-1995, we find some time-series variation in insecurity but no clear trends. We find that expectations and realizations of health insurance coverage and of jobs tend to match up quite closely, but respondents substantially overpredict the risk of burglary.
\end{abstract}

Jeff Dominitz

Institute for Social Research

University of Michigan

Ann Arbor, MI 48109
Charles F. Manski

Department of Economics

Social Science Building

University of Wisconsin

1180 Observatory Drive

Madison, WI 53706

and NBER 


\section{Introduction}

During the first few months of 1996, economic insecurity became a focus of media attention in the United States. The New York Times (March 3-9) ran a weeklong series on "The Downsizing of America," Business Week (March 11) devoted a cover story to "Economic Anxiety," and The Economist (April 6) offered its own perspective on "Learning to Cope" with economic insecurity. This public discourse coincided with policy proposals intended to reduce insecurity, such as the Kassebaum-Kennedy bill (S 1028) to increase the portability of health insurance and the "American Workers Economic Security Act" to reduce taxes on corporations which "treat workers fairly" and to restrain corporate mergers and acquisitions, among other provisions (Kennedy, 1996).

Attention to insecurity is by no means new. Advocating "some safeguards against misfortunes which cannot be wholly eliminated in this man-made world," Frankl in D. Roosevelt appointed a cabinet Committee on Economic Security in 1934 (reprinted in Davis, 1986, p.449). This committee's recommendations led to passage of the Social Security Act of 1935, creating a system of social insurance to partially insulate the population from the risk of economic hardship. Twenty years later, the Federal Reserve Board's Consultant Committee on Consumer Survey Statistics recommended that data be collected to monitor "popular feeling of anxiety and security" (reprinted in Tobin, 1959, p.10).

Since then, the federal government has invested substantially in the development of statistics that monitor the current status of the population, but not in statistics that monitor how Americans perceive their futures. Major national surveys such as the Current Population Survey, the Survey of Income and Program Participation, and the Panel Study of Income Dynamics describe the outcomes that individuals actually experience, but not the outcomes they expect 
to experience in the future.

A number of private survey organizations regularly elicit economic expectations. These measures of "consumer confidence" have generally not detected recent increases in economic insecurity. See, for example, the analysis of Gallup survey data by Newport and Saad (1996).

Perhaps the available survey data show no increase in insecurity because the apparent trend is simply an artifact of media hype in a presidential election year. Or perhaps increased insecurity is not detected because the surveys are not well-suited to monitor the phenomenon.

We have recently initiated the Survey of Economic Expectations (SEE) in an effort to learn how Americans perceive their near-term futures. SEE is a periodic module in WISCON, a national continuous telephone survey conducted by the Letters and Science Survey Center at the University of Wisconsin-Madison (see Winsborough, 1987). We measure respondents' perceptions of near-term economic insecurity through their responses to questions eliciting subjective probabilities of three events:

Health Insurance: "What do you think is the percent chance (what are the chances out of 100) that you will have health insurance coverage 12 months from now?"

Burglary: "What do you think is the percent chance (what are the chances out of 100) that someone will break into (or somehow illegally enter) your home and steal something, during the next 12 months?"

Job Loss: "What do you think is the percent chance that you will lose your job during the next 12 months?" 
All respondents are asked the first two questions, and those currently working are asked the third.

The use of probabilistic questions to elicit individuals' expectations has been recommended by Juster (1966), Savage (1971), Manski (1990), and Fischhoff (1994), each of whom concludes that probabilistic questions should yield more informative responses than do the qualitative expectations questions traditionally asked in surveys. In Dominitz and Manski (1996a), we consider three methods for learning about individuals' expectations--eliciting qualitative expectations, eliciting probabilistic expectations, and inferring expectations from realizations--and make the case for probability elicitation. Section 2 explains our thinking further.

Our empirical analysis begins in Section 3, which describes the SEE data. We focus on respondents interviewed in 1994 and 1995 who are labor force participants at the time of the interview. With item response rates exceeding 98 percent, respondents clearly are willing to answer the three subjective probability questions. Moreover, they appear to do so in a meaningful way.

In Section 4 we use the responses to classify individuals as relatively secure, relatively insecure, and highly insecure. We find that respondents with a high risk of one adverse outcome tend also to perceive high risks of the other outcomes. We find that economic insecurity tends to decline with age and with schooling. Black respondents perceive much greater insecurity than do whites, especially among males.

With only two years of data, we cannot provide an historical perspective on trends in economic insecurity but we can examine how expectations of economic misfortune have varied recently. This is done in Section 5 , where we find some time-series variation in insecurity but no clear trends. With the accumulation 
of data from subsequent administrations of the SEE, we anticipate that the timeseries data will help us to understand how changes in the real economy affect individuals' expectations and, conversely, how expectations affect the real economy.

The data we have already accumulated allow us to assess the extent to which the expectations of various groups of Americans accurately predict their subsequent realizations. In Section 6 , we find that expectations and realizations of health insurance coverage and of job loss tend to match up quite closely, but respondents substantially overpredict the risk of burglary.

Section 7 gives conclusions.

\section{Background}

What is economic insecurity? An individual's sense of economic insecurity may be thought to arise from his or her perceptions of the risk of economic misfortune. To monitor economic insecurity, analysts have used a variety of measures derived from responses to survey questions eliciting individual perceptions. In this section, we discuss these efforts. 1

1 Other analysts look instead to data on recent realizations. To ascertain the perceived risk of job loss, for example, researchers may use the local unemployment rate as a proxy. The inherently subjective nature of risk perceptions, however, limits the usefulness of measures based only on realizations data. See Manski (1993) and Dominitz and Manski (1996a). 


\subsection{Standard Approaches to Measuring Insecurity}

We decided to elicit subjective probabilities of health insurance coverage, burglary, and job loss after considering and rejecting standard survey measures of subjective economic insecurity. We have three main areas of concern about these measures, which we discuss here using as examples the questions posed by some national survey organizations. The areas of concern are: qualitative expectations, loosely-defined outcomes, and confounded phenomena.

Qualitative expectations:

Gallup Organization: Thinking about the next twelve months, how likely is it that your [husband/wife] will lose [his/her] job or be laid off -- is it very likely, fairly likely, not too likely, or not at all likely? (CNN/USA Today/Gallup Poll, April, 1996, Wave 1; see also Newport and Saad, 1996)

University of Michigan Survey Research Center (SRC): Now looking ahead -- do you think that a year from now you (and your family living there) will be better off financially, or worse off, or just about the same as now? (Curtin, 1982)

When asked to consider the prospects for a given economic outcome, such as the loss of one's job, respondents are often asked to report whether they "think," "expect," or "are worried" that the event will occur. Sometimes they are asked to report the strength of this belief or worry by attaching one of a 
choice of modifiers, such as "very," "fairly," "moderately, " or "not at all" likely/worried that the event will occur.

Perhaps the most basic problem concerns the interpersonal comparability of responses. Do different respondents interpret these verbal phrases in the same way? Empirical evidence indicates that interpretations of qualitative expectations questions vary substantially between respondents (see Wallsten et a1., 1986).

Even if respondents were to identically interpret these phrases, the coarseness of response options would limit the information contained in the responses. For example, a respondent to SRC's Survey of Consumer Attitudes, who must choose among "better," "worse," and "about the same," cannot express much about his or her prospects for financial well-being.

Loosely-defined outcomes:

New York Times: All in all, how economically secure do you feel? Very insecure, somewhat insecure,...? (New York Times, March 3, 1996)

Our concern about interpersonal comparability comes into even sharper focus when considering the outcomes about which respondents are asked. What does it mean to be "economically secure," as the New York Times asked earlier this year? How does the respondent reduce the many facets of economic security into one dimension? Do respondents interpret security as an absolute concept or as a relative one? If relative, to whom or to what time period does the respondent compare? Similar concerns apply to SRC's forward-looking financial well-being question (above) and to its backward-looking counterpart, which asks respondents 
to compare how well they "are getting along financially these days" to the situation one year earlier. These types of questions are asked by SRC (Curtin, 1982), the Conference Board (Linden, 1982), and the Gallup Organization (Newport and Saad, 1996), among others.

Confounded phenomena:

Harris: Compared to a year ago, do you feel more afraid and uneasy on the streets today, less uneasy, or not much different than you felt a few years ago? (Erskine, 1974)

Ferraro and LaGrange (1987) argue that "fear of crime" questions generally confound two concepts--the perceived risk of crime and the emotional response to crime--which need not be strongly correlated. In fact, they argue that the empirical evidence suggests these two phenomena are not strongly positively related and, for some criminal activities, may be negatively related. Responses to this type of survey question may therefore provide inefficient, if not invalid, indicators of the perceived risk of crime victimization.

The confounding of two distinct phenomena in a single indicator also characterizes measures of consumer confidence. For example, SRC's Index of Consumer Sentiment is derived from responses to a series of five questions, including the two financial well-being questions previously discussed (see Zagorski and McDonnel1, 1995). Changes in this measure are said to reflect changes in both optimism/pessimism and certainty/uncertainty (see Curtin, 1982, and Throop, 1992). While inspection of the questions leaves us to wonder about the mechanism by which subjective uncertainty is conveyed, it is clear that no 
single indicator can be well-suited to capture changes in two phenomena, unless these phenomena are strongly positively related. We know of no empirical evidence to substantiate such a claim.

\subsection{New Approaches to Measuring Insecurity}

We seek to elicit subjective probabilities of well-defined prospective outcomes. These responses may be used to construct measures of economic insecurity (see Section 4). A number of recent studies have elements in common with our strategy to measure economic insecurity. We discuss some of them briefly before proceeding to the analysis of our data.

The HRS/AHEAD Surveys: In 1992, SRC began two companion panel surveys of 51 to 61 year-old and of over-70 year-old Americans, entitled the Health and Retirement Study (HRS) and the Asset and Health Dynamics among the 01dest 01d (AHEAD) surveys, respectively (see Juster and Suzman, 1995). In addition to many questions on outcomes actually realized, respondents are asked a number of questions eliciting the subjective probability of living to age $75 / 85$, job loss, entering a nursing home, and medical expenses using up all savings, among other events. Thus far, analyses of these data have focused on expectations of one outcome at a time, such as mortality (Hurd and McGarry, 1995) or nursing home utilization (Holden et al., 1995).

The Italian SHIW and Dutch VSB-Panel Surveys: Two European surveys include questions eliciting subjective probabilities of one-year-ahead growth rates in income. Responses to the Bank of Italy's 1989 Survey of Household Income and 
Wealth (SHIW) have been analyzed by Guiso et a1. (1992), who focus on the effect of income uncertainty on savings behavior. We are not aware of any analyses of responses to similar questions contained in the more recent, continuing VSB-Panel survey conducted by the Center for Economic Research in Tilburg, Netherlands.

The Carnegie Mellon Studies of Risk Perceptions: The Social and Decision Sciences group at Carnegie Mellon University has undertaken a series of smal1scale studies (e.g., less than 300 subjects drawn from the Pittsburgh area) eliciting subjective probabilities of various events. For example, Quadrel et a1. (1993) report findings from a diverse sample of adults and adolescents on their perceived risks of becoming alcohol dependent, getting mugged, and becoming sick from pesticide poisoning, among other adverse outcomes.

The Madison Study of Student Expectations: In Dominitz and Manski (1996b), we describe the results of a survey in Madison, Wisconsin eliciting from 71 high school students and 39 college undergraduates their expectations of the income they would earn if they were to complete different levels of schooling. The questions elicited expectations in the form of subjective probabilities.

The Torino-Budapest Study of Socio-Economic Security: A group of sociologists conducted a survey of 249 adults in Torino, Italy and 409 adults in Budapest, Hungary in 1988 (Garner and Garner, 1991). Respondents were asked to report the likelihood of job loss, crime victimization, moving because of eviction or rent increase, and having a sufficient pension, among other outcomes. Responses were given in the form of verbal quantifiers--very probable, probable, improbable, very improbable. An index of economic security was constructed from 
these responses.

The 1993 Survey of Economic Expectations: The first version of SEE, administered during 1993, elicited respondents' one-year-ahead expectations of income, earnings, and employment (see Dominitz, 1994, and Dominitz and Manski, 1996a). This study served as a proving ground for the series of questions contained in the current, continuing survey. The income and employment questions have been revised and supplemented, and the earnings questions have been replaced by questions on health insurance coverage and crime victimization.

\section{Eliciting Subjective Expectations}

3.1. The 1994-1995 Survey of Economic Expectations

We placed our set of probabilistic expectations questions as a periodic module in WISCON, an ongoing national telephone survey conducted by the Letters and Science Survey Center (LSSC) at the University of Wisconsin-Madison. The WISCON survey core questions ask respondents about their labor market experiences, demographics, and household income. Our module was included during the periods April to July 1994 (henceforth, mid 1994), November 1994 to January 1995 (end 1994), May to July 1995 (mid 1995), and November 1995 to January 1996 (end 1995). The interviewing intensity varied across the time periods, but the samples were drawn from the same population of American households with telephones via the same random-digit dialing algorithm. LSSC completed 971 interviews in mid 1994, 480 in end 1994, 774 in mid 1995, and 661 in end 1995. 
The respondent selection rule chooses one adult person to interview from each contacted household; hence adults living in single-adult households are drawn with higher probability than adults living in multiple-adult households. In Sections 4,5 , and 6 , where we generalize our results to the U.S. labor force, we present weighted estimates that adjust for differential respondent-selection probabilities across households and time periods.

The module of expectations questions was prefaced by the following set of instructions read to respondents:

Now I will ask you some questions about future, uncertain outcomes. In each case, try to think about the whole range of possible outcomes and think about how likely they are to occur during the next 12 months. In some of the questions, I will ask you about the PERCENT CHANCE of something happening. The percent chance must be a number from 0 to 100 . Numbers 1 ike:

2 or 5 percent may be "almost no chance"

20 percent or so may mean "not much chance"

a 45 or 55 percent chance may be a "pretty even chance"

80 percent or so may mean a "very good chance"

and a 95 or 98 percent chance may be "almost certain"

The percent chance can also be thought of as the number of CHANCES OUT OF 100.

Our analysis focuses on the 2060 respondents who were in the labor force at the time of the interview and who gave valid responses to the three questions on economic insecurity. Respondents are defined to be in the labor force if they 
state that, at the time of the interview, they are either working for pay, temporarily absent from a job, or looking for work. We exclude persons not in the labor force because job loss probabilities are not meaningful for them. Among the respondents who are in the labor force, we elicited job-loss expectations only from those who are currently working. This group constitutes about ninety percent of the labor force participants and it was necessary to impute job-loss expectations to the remaining ten percent. ${ }^{2}$

\subsection{Response Rates}

The WISCON interviewers attempt to contact about twenty households per day and obtain an interview from slightly over fifty percent of the selected households. The nonresponse is fairly evenly divided between refusals to be interviewed and cases in which repeated phone calls find the appropriate respondent to be not at home or otherwise unable to complete the interview.

Our expectations questions were administered to 2886 WISCON respondents, 55 percent of whom were women, indicating that nonresponse rates differ somewhat by gender. The sample includes 2102 labor force participants, 1063 men and 1039 women. The respective male and female labor force participation rates of .82 and .65 exceed those typically found in recent Current Population Survey data by five or six percentage points, for both men and women.

Table 1 reports the demographic and schooling characteristics of the

2 We assign 1.00 as the subjective probability of job loss to the 88 respondents who were unemployed at the time of the interview; that is, to those who did not have a job and were looking for work. We assign 0.05 as the subjective probability of job loss to the 135 respondents who stated that they were "temporarily absent" from a job at the time of the interview. The value 0.05 is the population-wide median job-loss probability of employed persons. 
respondents. The first column describes the entire sample of 2886 individuals, and the second column describes our sample of 2060 labor force participants who gave valid responses to each of the economic insecurity questions. Weighted fractions, which adjust for differential selection probabilities across households and time, are given for each schooling and demographic group in column four. The weighted fractions are very close to their unweighted counterparts in column three.

Overall, 98 percent of labor force participants (2060 out of 2102) responded to the economic insecurity questions. Rates of response vary negligibly across the groups described in Table 1 . The item response rate is less than 95 percent in only one group, women aged 65 or more, among whom 39 out of 44 responded.

\subsection{Are the Responses Meaningful?}

The feasibility and utility of eliciting subjective probabilities in household surveys is a subject of some controversy among researchers. While probabilistic questions should yield more informative responses than do the qualitative expectations questions traditionally asked in surveys, a diverse literature suggests that respondents may think about uncertain events using less than the full structure of modern probability theory. See Camerer and Webber (1992).

If respondents have difficulty thinking in terms of subjective probabilities, then perhaps they will be unwilling to respond to probabilistic expectations questions. Our very high rates of item response indicate otherwise, as do the high response rates generally obtained in the other studies described 
in Section 2.2.

Willingness to respond, however, does not imply that the responses are meaningful. Perhaps responses are simply given in a perfunctory manner. There is no definitive way to assess the seriousness with which respondents answer our questions, but we can look for response patterns that may indicate a lack of care. In particular, we can examine the extent of bunching at round numbers.

For each of the three events -- no health insurance coverage, burglary, and job loss--Table 2 reports the complete frequency distribution of responses given by the 2060 respondents. ${ }^{3}$ The entries in Table 2 indicate that each event tends to be perceived as unlikely to occur, with the overwhelming majority of responses falling in the lower half of the percent-chance scale. Responses appear to be rounded to the nearest multiple of 5, except at such low values as 1 or 2 percent.

A fear commonly expressed by researchers skeptical of probability elicitation is that respondents will concentrate their responses on the values 0,50 , and 100. Table 2 documents many reports of a 0 percent chance (almost one-third of all responses), but many of these responses presumably are cases where a respondent perceives less than a l percent chance of the event and simply rounds down. Even if the responses are rounded down from somewhat higher values, this type of rounding error should not greatly affect the results presented below. Quadrel et al. (1993) are fundamentally interested in separating zero from non-zero probabilities and adopt methods designed to induce more precise responses.

3 Responses to the health insurance question have been subtracted from 100 , yielding the percent chance of not being covered rather than of being covered. We make this transformation to focus on the likelihood of adverse outcomes in each of the three cases. 
We do find more bunching at the value 50 than at other nearby multiples of 5. We have investigated the extent of this bunching conditional on various behaviors and on attributes of respondents. We find that respondents who report a 50 for one question are more likely to report the same value for another question, but this association is not strong. For example, eleven percent of all respondents report a 50 for the burglary question, whereas nineteen percent of those reporting a 50 for the health insurance question also do so for the burglary question. In personal communications, some researchers have asserted that less educated respondents have the most difficulty with probabilistic questions. We find that respondents with no more than a high school diploma are only slightly more likely than others to report a 50 (e.g., thirteen percent report a 50 for the burglary question).

\subsection{The Sample Distribution of Risk Perceptions}

We can summarize the central tendency of the responses reported in Table 2 by giving their sample means and medians. For health insurance, the sample mean and median subjective probabilities are .15 and .02 . For burglary, they are .17 and .10 . For job loss, they are .18 and .05. Observe that each sample mean is much larger than the corresponding sample median. This reflects the skewness of the sample distributions. Table 2 shows that, in each case, a majority of the respondents place negligible or small subjective probability on the event, but some respondents think the event moderately or even very likely to occur.

To more fully summarize the heterogenity of risk perceptions we present several quantiles of the sample distribution of the responses: 
Sample Means and Quantiles of the Subjective Probabilities

No Health Insurance

Mean

$\begin{array}{llll}.25 & .50 & .75 \\ .15 & .00 & .02 & .20\end{array}$
Victim of Burglary

Mean Quantile

$\begin{array}{llll}.17 & .02 & .10 & .20\end{array}$
Job Loss

Mean Quantile

$.25 \quad .50 \quad .75$

$\begin{array}{llll}.18 & .00 & .05 & .20\end{array}$

Consider, for example, the perceived risk of job loss. At least twenty-five percent of the respondents (the .25-quantile) see themselves as facing zero chance of losing their jobs in the next year. At least fifty percent of the respondents (the .50-quantile or median) see themselves as facing no more than a .05 chance of job loss. But some do not feel so secure. The entry for the .75-quantile shows that up to twenty-five percent of respondents see themselves as facing a .20 chance or more of job loss in the next year. Other quantiles may be derived directly from Table 2 .

\section{The Concentration of Insecurity}

\subsection{Measuring Insecurity}

In Section 3 we described some basic features of the SEE sample data. From here on, we use those data to draw conclusions about the risk perceptions of the American population. To this end, we henceforth weight the sample data to adjust for differential respondent-selection probabilities across households and across time periods.

First consider the three events one at a time. Table 3 characterizes the distribution of risk perceptions within various groups defined by gender, age, 
education, race, and employment status. Observe that, in every group, the mean subjective probability of each event is much higher than the corresponding median. Thus our earlier finding of skewness in the sample distribution of risk perceptions persists when we examine the risk perceptions of subpopulations of Americans.

Considering the three events one at a time does not reveal the extent to which insecurity is concentrated within the population. Do most Americans perceive a high risk of at least one adverse outcome, or rather do some perceive high risks of all three events while others perceive themselves to be relatively immune?

Let $\left(p_{1}, p_{2}, p_{3}\right)$ denote a person's subjective probabilities of the three events -- no health insurance, burglary, and job loss. The estimated populationwide median values of the subjective probabilities of these events are $(.02, .10, .05)$ and the .75 -quantile subjective probability values are $(.20, .20, .20)$. To measure the concentration of insecurity within various groups, we report in Table 4 the fraction $F\left(p_{1}<.02, p_{2}<.10, p_{3}<.05\right)$ of group members whose subjective probabilities all lie below the respective population medians. We refer to these persons as relatively secure. We report the fraction $F\left(p_{1}>.02, p_{2}>.10, p>.05\right)$ of group members whose subjective probabilities all exceed the population medians. We refer to these persons as relatively insecure. We also compute the fraction $F\left(p_{1}>.20, p_{2}>.20, p_{3}>.20\right)$ of group members whose subjective probabilities all exceed the population .75-quantiles. We refer to these persons as highly insecure.

As reported in the top row of Table 4, we estimate that 16 percent of men are relatively secure and 14 percent are relatively insecure, according to these definitions, leaving 70 percent in the intermediate group who are neither secure 
nor insecure. Highly insecure individuals constitute 4 percent of the male labor force. Similarly, among women, 16 percent are relatively secure, 13 percent are relatively insecure, and 3 percent are highly insecure.

These results indicate that persons with a high subjective probability of one event tend also to have high subjective probabilities of the other events. If $p_{1}, p_{2}$, and $p_{3}$ were statistically independent of one another, 10 (9) percent of men (women) would be relatively secure, 6 (7) percent would be relatively insecure, and l (1) percent would be highly insecure. ${ }^{4}$ Instead, we find these percentages to be 16,14 , and 4 among men, and $16,13,3$ among women. These substantially larger values indicate that the subjective probabilities $p_{1}, p_{2}$, and $P_{3}$ are not statistically independent but rather are positively associated within the labor force.

In Section 2, we identified weaknesses in previous attempts to measure insecurity. We recognize that Table 4 also has its limitations. Perhaps most significantly, we may have ignored important dimensions of insecurity. We do not incorporate perceived risks to retirement savings or to home ownership, for example. While we do include the risk of job loss, we do not include perceptions of the loss of income associated with job loss. An advantage of our approach is the natural way in which such additional dimensions may be included. If the probabilities of other adverse outcomes are elicited, the classifications may be redefined to incorporate the additional dimensions. In the meantime, we are

${ }^{4}$ Let $j=1,2,3$. If the empirical distribution of $p_{j}$ were continuous, half of all respondents would have $p_{j}$ less than the empirical median and half would have $p_{j}$ greater than the empirical median. A quarter would have $p_{j}$ greater than the empirical .75-quantile. Hence, under the statistical independence assumption, the fractions relatively secure and relatively insecure would each be $(.5)^{3}=.125$, and the fraction highly insecure would be $(.25)^{3}=.016$. Because the empirical distributions are discrete with some mass at their medians and .75-quantiles, these fractions turn out to have the values .097, .066, .009 among men, and the values .092, .073, and .015 among women. 
satisfied that the three events we have selected capture an inherently interesting array of risks.

\subsection{Variation in Insecurity across Groups}

How do risk perceptions vary across subgroups of the population? Tables 3 and 4 show that males and females have very similar overall distributions of risk perceptions but somewhat different patterns by age and schooling. Among females under age 65 , the fraction relatively secure increases substantially with age from .13 (18-34 year-olds) to .27 (50-64 year-olds), while the fraction relatively insecure decreases from .14 to .09 . Table 3 reveals that the subjective probabilities of each of the three events tend to decrease with age. A weaker pattern emerges with respect to schooling. The fraction relatively insecure decreases from .16 (high school diploma or less) to .10 (bachelor's degree or more), but the fraction relatively secure does not vary monotonically. It is the subjective probability of no health insurance that decreases most clearly with schooling.

Among males, the variation with respect to age is similar to that found among females, but the variation with schooling levels is much more striking. Whether the event be lack of health insurance or burglary, the subjective probabilities of males with a bachelor's degree tend to be less than half the magnitudes of those with no more than a high school diploma. The job loss probabilities also tend to be lower. Among males with a bachelor's degree, only .07 are relatively insecure and .02 are highly insecure. Among those with no more than a high school diploma, .19 are relatively insecure and .07 are highly insecure. 
Tables 3 and 4 show that whites and blacks have very different distributions of risk perceptions, with blacks tending to report much greater perceived insecurity than do whites. The racial pattern is apparent among both males and females but is particularly strong among males. Whether the event be lack of health insurance, burglary, or loss of job, black males report substantially higher subjective probabilities than do white males. Fully .18 of black males are highly insecure. The fraction among white males is just .02.

The tables also describe the risk perceptions of persons who currently are both employed and covered by health insurance. This group, which constitutes an estimated 79 percent of the labor force, may be thought of as the relatively well-off core of the labor force in terms of current economic status. Being we11-off at a point in time does not, however, imply that one is secure. We see, for example, that .13 of this group of males are relatively insecure, a fraction which exceeds the .07 of males with a bachelor's degree, regardless of employment and insurance status. More generally, we see that the fraction relatively insecure among employed, insured persons is one or two points lower than that of the general labor force, whereas the fraction relatively secure is two or three points higher. 


\section{Trends in Risk Perceptions}

We undertook this study to monitor economic insecurity. Thus far, we have investigated the extent to which insecurity varies across and is concentrated within segments of the labor force. We also aim to monitor variation in insecurity over time. Our ability to track changes over time is limited because the data collected to date span only two years. In previous sections, we have pooled the four quarters of data--mid 1994, end 1994, mid 1995, and end 1995. In this section, we distinguish the time periods.

Table $5 \mathrm{~A}$ describes the population distribution of the subjective probabilities in each of the four quarters. Table 5B reports our measures of the concentration of insecurity. Of the three events, perceptions of the risk of burglary appear the most stable and the job loss probabilities are the most volatile.

Some differences between the perceptions of males and females are apparent. Among males, the perceived risks of no health insurance and job loss tended to decrease from mid 1994 to end 1994 before rising in mid 1995 and falling in end 1995, yielding concomitant fluctuations in the insecurity measures. Among females (focusing on the population mean and .75-quantile), job loss probabilities tended to increase from mid 1994 to end 1994 before falling in successive quarters. Our measures of economic insecurity give no clear picture of changes in insecurity among females across these time periods.

It is of interest to compare the trends in risk perceptions revealed by the SEE instrument to the trends observed in other indicators of economic expectations. One such measure is SRC's Index of Consumer Expectations (ICE). The ICE is constructed from responses to questions eliciting qualitative 
expectations of family financial well-being and business conditions, as well as assessments of "buying conditions" (e.g., a "good time" or "bad time" to buy). The ICE averaged 82.0 in mid $1994,87.3$ in end $1994,83.9$ in mid 1995, and 80.7 in end 1995 (Survey Research Center, 1996). The Index of Consumer Sentiment, which incorporates responses to two backward-looking questions on family financial well-being and business conditions as well as the components of the ICE, averaged 106.1 (mid 1994), 106.3 (end 1994), 105.4 (mid 1995), and 103.2 (end 1995). Each of these measures therefore exhibited a steady, if relatively slight, decline from mid 1994 to end 1995.

\section{The Objective Accuracy of Elicited Risk Perceptions}

In two distinct senses, we would like to determine the accuracy of the risk perceptions that we elicit from respondents. First, we would like to know how well the elicited subjective probabilities measure what persons really think about their risks of health insurance coverage, burglary, and job loss in the next year. Second, we would like to know how objectively accurate are the reported risk perceptions.

We cannot offer any really satisfying way to assess accuracy in the first sense. Every effort to interpret responses to subjective questions runs up against the generic problem that a researcher cannot directly observe a respondent's thinking. We do judge the pattern of responses to be reasonable. The findings presented in Section 3 indicate that respondents are willing to answer the questions and do so in more than a perfunctory manner. The findings in Section 4 make sense to us--the positive intra-person association among the 
subjective probabilities of the three events, the broad similarity of the risk perceptions of males and females, the patterns of insecurity by age and schooling, and the substantial difference in insecurity between whites and blacks.

Perhaps the cleanest way to assess the objective accuracy of elicited expectations is to re-interview respondents a year later, learn about their experiences during the year, and compare the realized events with the expectations elicited a year earlier. Such comparisons are straightforward if one is willing to assume that realized events are statistically independent across respondents. In this vein, Dominitz (1995) uses a one-year follow-up to the 1993 version of SEE to assess the objective accuracy of respondents' earnings expectations.

Respondents to the 1994 and 1995 version of SEE have not been recontacted, and so we cannot use this approach to assess the objective accuracy of their elicited risk perceptions. We can, however, assess objective accuracy by comparing the expectations elicited in 1994 to the realizations reported by members of the same group in 1995.

A11 SEE respondents were asked these three questions:

Realized Health Insurance: Do you have any health insurance coverage?

Realized Burglary: During the past 12 months, did anyone break into or somehow illegally get into your home and steal something?

Realized Job Loss: Have there been any times during the past 12 months when you did not have a job and were looking for work? 
The first two questions elicit realizations of the same events about which the expectations questions ask. The job loss question, which is one of the core WISCON questions, does not correspond as well to the expectations question. 5

Suppose that the realizations of health insurance, burglary, and job loss are statistically independent across respondents. Subject to this assumption, we can assess the objective accuracy of elicited risk perceptions by comparing population mean subjective probabilities reported in 1994 with corresponding realized rates of occurrence reported in 1995. Table 6 presents this comparison using data from the 1036 labor force participants in 1994 and the 1024 labor force participants in 1995.

The findings are striking. The expectations and realizations of health insurance and job loss match up closely. Among men (women), the mean subjective probability of no health insurance is $.15(.16)$, and the subsequent proportion without insurance in 1995 is .15 (.13). The mean job loss probability is .15 (.21) among men (women), and the subsequent rate of realization is $.18(.18)$. The picture is quite different with respect to crime victimization. Whereas only .03 of all women report in 1995 that they were victims in the past year, the mean subjective probability of being burglarized (among 1994 women) was .17. Discrepancies of this general magnitude show up across the board, in every demographic and schooling group, among both males and females.

We can offer no compelling rationale for the large discrepancy between

5 The comparison is appropriate under the following two conditions: (i) a11 unemployed job seekers over the past 12 months have lost a job rather than left one voluntarily or recently entered the labor force and (ii) all job losers over the past 12 months have spent some time as unemployed job seekers and did not exit the labor force. Should condition (i) fail to hold, then we would overstate the proportion of the labor force with realized job losses. Should condition (ii) fail to hold, then we would understate the proportion with realized job losses. 
expectations and realizations of burglary. Our findings do seem to corroborate the conventional wisdom that Americans perceive crime to be far more prevalent than it actually is (see Bursik and Grasmick, 1993, Chapter 4).

\section{Conclusion}

This study has presented evidence on American perceptions of personal, near-term economic insecurity during 1994 and 1995. Our method of monitoring insecurity diverges substantially from standard survey methods, but it does have elements in common with a series of recent studies in the U.S. and in Europe. We find this approach to be promising, but we do not assert that we have developed the best method possible. We believe that measures of insecurity should be derived from reported subjective probabilities of a variety of welldefined, adverse outcomes. The elicitation method, choice of outcomes, and measure of insecurity are three subjects deserving further consideration.

We would also like to assess the effects of insecurity. Economic theory suggests that income risk induces individuals to increase savings, thereby decreasing consumption. Heightened fear of crime may cause individuals to take precautions in their daily activities. Risks to health insurance coverage may keep workers from switching jobs, yielding the phenomenon of "job lock." Economic insecurity may also adversely affect an individual's mental or physical health (see Catalano, 1991). To make progress on these issues, we see the need for simultaneous collection of data on actual behaviors thought to be related to economic insecurity. 


\section{References}

Bursik, R. and H. Grasmick (1993), Neighborhoods and Crime, New York: MacMillan.

Camerer, C. and M. Webber (1992), "Recent Developments in Modeling Preferences: Uncertainty and Ambiguity," Journal of Risk and Uncertainty, 5: 325-370.

Catalano, R. (1991), "Health Effects of Economic Insecurity," American Journal of Public Health, 81: 1148-1152.

Curtin, R. (1982), "Indicators of Consumer Behavior: The University of Michigan Surveys of Consumers," Public 0pinion Quarterly, 46: 340-352.

Davis, K. (1986), FDR: The New Deal Years, New York: Random House.

Dominitz, J. (1994), Subjective Expectations of Unemployment, Earnings, and Income, Ph.D. dissertation, University of Wisconsin-Madison.

Dominitz, J. (1995), "Earnings Expectations, Revisions, and Realizations," Institute for Social Research, University of Michigan.

Dominitz, J. and C. Manski (1996a), "Using Expectations Data to Study Subjective Income Expectations, "Social Systems Research Institute, University of WisconsinMadison.

Dominitz, J. and C. Manski (1996b), "Eliciting Student Expectations of the Returns to Schooling," The Journal of Human Resources, 31:1-26.

Erskine, H. (1974), "The Polls: Fear of Violence and Crime," Public Opinion Quarterly, 38: 131-145.

Ferraro, K. and R. LaGrange (1987), "The Measurement of Fear of Crime," Sociological Inquiry, 57: 70-101.

Fischhoff, B. (1994), "What Forecasts (Seem To) Mean," International Journal of Forecasting, 10: 387-403.

Garner, R. and L. Garner (1991), "Socio-Economic Security and Insecurity in Socialist and Capitalist Political Economies: A Survey of Two European Cities," Science and Society, 55: 5-25.

Guiso, L., T. Jappelli, and D. Terlizzese (1992), "Earnings Uncertainty and Precautionary Saving," Journal of Monetary Economics, 30: 307-337.

Juster, T. (1966), "Consumer Buying Intentions and Purchase Probability: An Experiment in Survey Design," Journal of the American Statistical Association, 61: 658-696.

Juster, T. and R. Suzman (1995), "An Overview of the Health and Retirement Study," Journal of Human Resources, 30: 57-S56. 
Holden, K., T. McBride, and M. Perozek (1995), "Expectations of Nursing Home Use in the Health and Retirement Survey: The Role of Race, Health, and Family Structure," presented at the Minority Perspectives in the Health and Retirement Survey Workshop, Institute for Social Research, Ann Arbor, MI.

Hurd, M. and K. McGarry (1995), "Evaluation of the Subjective Probabilities of Survival in the Health and Retirement Study, Journal of Human Resources, 30: S268-S292.

Kennedy, E. (1996), Statement of Senator Kennedy Regarding Introduction of the American Workers Economic Security Act, Office of U.S. Senator Edward M. Kennedy, April 15.

Linden, F. (1982), "The Consumer as Forecaster, " Public Opinion Quarterly, 46: 353-360.

Manski, C. (1990), "The Use of Intentions Data to Predict Behavior: A Best Case Analysis," Journal of the American Statistical Association, 85: 934-940.

Manski, C. (1993), "Adolescent Econometricians: How Do Youth Infer the Returns to Schooling?" in Studies of Supply and Demand in Higher Education, eds. C. Clotfelter and M. Rothschild, Chicago: University of Chicago Press.

Newport, F. and L. Saad (1996), "The Economy and the Election," The Public Perspective, April/May, 1-4.

Quadrel, M., Fischhoff, B., and Davis, W. (1993), "Adolescent (In)vulnerability," American Psychologist, 48: 102-116.

Savage, L. (1971), "Elicitation of Personal Probabilities and Expectations," Journal of the American Statistical Association, 66: 783-801.

Smith, T. (1985), "The Polls: America's Most Important Problems Part I: National and International," Public Opinion Quarterly, 49: 264-274.

Survey Research Center (1996), "Surveys of Consumers," University of Michigan, Ann Arbor, MI, March.

Throop, A. (1992), "Consumer Sentiment: Its Causes and Effects," San Francisco Economic Review, Winter.

Tobin, J. (1959), "On the Predictive Value of Consumer Intentions and Attitudes, " Review of Economics and Statistics, 41: 1-11.

Wallsten, T., D. Budescu, A. Rapaport, R. Zwick, and B. Forsyth (1986), "Measuring the Vague Meaning of Probability Terms," Journal of Experimental Psychology: General, 115: 348-365.

Winsborough, H. (1987), "The WISCON Survey: Wisconsin's Continual Omnibus, National Survey, " Center for Demography and Ecology, University of WisconsinMadison. 
Zagorski, K. and J. McDonnell (1995), "'Consumer Confidence' Indexes as Social Indicators," Social Indicators Research, 36: 227-246. 
Table 1: Characteristics of the Respondents

$\begin{array}{lll}\text { WISCON } & \text { SEE } & \begin{array}{l}\text { Composition of SEE Sample } \\ \text { Unweighted }\end{array} \\ \text { Sample } & \text { Sample } & \text { Weighted }\end{array}$

\begin{tabular}{|c|c|c|c|c|}
\hline Al1 & 2886 & 2060 & 1.00 & 1.00 \\
\hline Male & 1293 & 1045 & 0.51 & 0.51 \\
\hline $\begin{array}{ll}\text { Age } & 18-34 \\
\text { Age } & 35-49 \\
\text { Age } 50-64 \\
\text { Age } 65 \text { or more }\end{array}$ & $\begin{array}{l}429 \\
460 \\
233 \\
160\end{array}$ & $\begin{array}{r}406 \\
425 \\
177 \\
32\end{array}$ & $\begin{array}{l}0.20 \\
0.21 \\
0.09 \\
0.02\end{array}$ & $\begin{array}{l}0.20 \\
0.20 \\
0.09 \\
0.01\end{array}$ \\
\hline $\begin{array}{l}\text { No College } \\
\text { Some College } \\
\text { Bachelor Degree }\end{array}$ & $\begin{array}{l}340 \\
480 \\
463\end{array}$ & $\begin{array}{l}239 \\
417 \\
385\end{array}$ & $\begin{array}{l}0.12 \\
0.20 \\
0.19\end{array}$ & $\begin{array}{l}0.12 \\
0.21 \\
0.18\end{array}$ \\
\hline $\begin{array}{l}\text { White } \\
\text { Black }\end{array}$ & $\begin{array}{r}1071 \\
76\end{array}$ & $\begin{array}{r}856 \\
62\end{array}$ & $\begin{array}{l}0.42 \\
0.03\end{array}$ & $\begin{array}{l}0.42 \\
0.03\end{array}$ \\
\hline $\begin{array}{l}\text { Employed with } \\
\text { Health Insurance }\end{array}$ & 823 & 811 & 0.39 & 0.40 \\
\hline Female & 1593 & 1015 & 0.49 & 0.49 \\
\hline $\begin{array}{l}\text { Age } 18-34 \\
\text { Age } 35-49 \\
\text { Age } 50-64 \\
\text { Age } 65 \text { or more }\end{array}$ & $\begin{array}{l}471 \\
495 \\
297 \\
314\end{array}$ & $\begin{array}{r}382 \\
412 \\
175 \\
39\end{array}$ & $\begin{array}{l}0.19 \\
0.20 \\
0.08 \\
0.02\end{array}$ & $\begin{array}{l}0.19 \\
0.20 \\
0.08 \\
0.02\end{array}$ \\
\hline $\begin{array}{l}\text { No College } \\
\text { Some College } \\
\text { Bachelor Degree }\end{array}$ & $\begin{array}{l}492 \\
661 \\
437\end{array}$ & $\begin{array}{l}241 \\
454 \\
318\end{array}$ & $\begin{array}{l}0.12 \\
0.22 \\
0.15\end{array}$ & $\begin{array}{l}0.12 \\
0.22 \\
0.14\end{array}$ \\
\hline $\begin{array}{l}\text { White } \\
\text { Black }\end{array}$ & $\begin{array}{r}1328 \\
123\end{array}$ & $\begin{array}{r}834 \\
84\end{array}$ & $\begin{array}{l}0.40 \\
0.04\end{array}$ & $\begin{array}{l}0.40 \\
0.04\end{array}$ \\
\hline $\begin{array}{l}\text { Employed with } \\
\text { Health Insurance }\end{array}$ & 801 & 784 & 0.38 & 0.39 \\
\hline
\end{tabular}

The WISCON sample includes all persons interviewed in the relevant time periods. The SEE sample are those WISCON respondents who are in the labor force and who respond to the three expectations questions. The weighted fractions reflect differential respondent-selection probabilities across households and time periods. 
Table 2: Frequencies of Expectations Responses, Respondents in Labor Force

$\begin{array}{lrrr}\begin{array}{l}\text { Percent } \\ \text { Chance }\end{array} & \begin{array}{r}\text { No Health } \\ \text { Insurance }\end{array} & \begin{array}{r}\text { Victim of } \\ \text { Burglary }\end{array} & \text { Job Loss } \\ 0 & & & \\ 1 & 960 & 286 & 648 \\ 2 & 58 & 88 & 92 \\ 2 & 92 & 154 & 124 \\ 3 & 2 & 32 & 17 \\ 4 & 2 & 5 & 1 \\ 5 & 154 & 339 & 373 \text { (135 imputed) } \\ 6-9 & 2 & 14 & 5 \\ 10 & 197 & 339 & 197 \\ 11-14 & 1 & 3 & 1 \\ 15 & 23 & 48 & 26 \\ 16-19 & 0 & 1 & 0 \\ 20 & 151 & 228 & 117 \\ 21-24 & 1 & 1 & 0 \\ 25 & 53 & 65 & 32 \\ 26-29 & 0 & 0 & 0 \\ 30 & 25 & 87 & 46 \\ 31-34 & 0 & 1 & 0 \\ 35 & 4 & 8 & 4 \\ 36-39 & 0 & 0 & 0 \\ 40 & 26 & 36 & 20 \\ 41-44 & 0 & 0 & 0 \\ 45 & 5 & 14 & 5 \\ 46-49 & 0 & 0 & 0 \\ 50 & 151 & 221 & 130 \\ 51-54 & 0 & 0 & 0 \\ 55 & 3 & 2 & 2 \\ 56-59 & 0 & 0 & 0 \\ 60 & 15 & 16 & 13 \\ 61-64 & 0 & 0 & 0 \\ 65 & 2 & 3 & 3 \\ 66-69 & 1 & 0 & 0 \\ 70 & 10 & 4 & 11 \\ 71-74 & 1 & 0 & 0 \\ 75 & 8 & 10 & 17 \\ 76-79 & 0 & 0 & 0 \\ 80 & 25 & 20 & 24 \\ 81-84 & 0 & 0 & 0 \\ 85 & 2 & 2 & 5 \\ 86-89 & 0 & 0 & 0 \\ 90 & 18 & 7 & 8 \\ 91-94 & 0 & 1 & 0 \\ 95 & 9 & 2 & 8 \\ 96-99 & 51 & 8 & 6 \\ 100 & 2060 & 2060 & 2060 \\ \text { A11 } & & & \end{array}$


Table 3: Population Means and Quantiles of the Subjective Probabilities

No Health Insurance Victim of Burglary

Quantile

mean $.25 \quad .50 \quad .75$

Male

Age 18-34

$\begin{array}{llll}.14 & .00 & .02 & .20\end{array}$

(.01) $\quad(.00)(.00)(.02)$

$\begin{array}{llll}.18 & .00 & .05 & .25\end{array}$

(.02) (.00)(.02) (.05)

Age 35-49

$\begin{array}{llll}.14 & .00 & .02 & .20\end{array}$

(.01) $\quad(.00)(.01)(.04)$

Age 50-64

$\begin{array}{llll}.10 & .00 & .00 & .10\end{array}$

(.01) $(.00)(.00)(.03)$

Age $65+\quad .06 \quad .00 \quad .00 \quad .05$

(.03) $(.00)(.01)(.03)$

$\begin{array}{lllll}\text { No College } & .22 & .00 & .05 & .40\end{array}$

(.02) (.00) (.03) (.09)

$\begin{array}{lllll}\text { Some College } & .16 & .00 & .05 & .20\end{array}$

(.01) $\quad(.00)(.02)(.02)$

Bachelor Degree .08 $\quad .00 \quad .00 \quad .05$

$$
\text { (.01) }(.00)(.00)(.02)
$$

White

$$
\begin{array}{llll}
.13 & .00 & .01 & .10
\end{array}
$$$$
\text { (.01) (.00) }(.01)(.03)
$$

Black

$$
\begin{array}{llll}
.25 & .00 & .20 & .50 \\
(.04) & (.02) & (.09) & (.07)
\end{array}
$$

Employed

w/Health Ins.

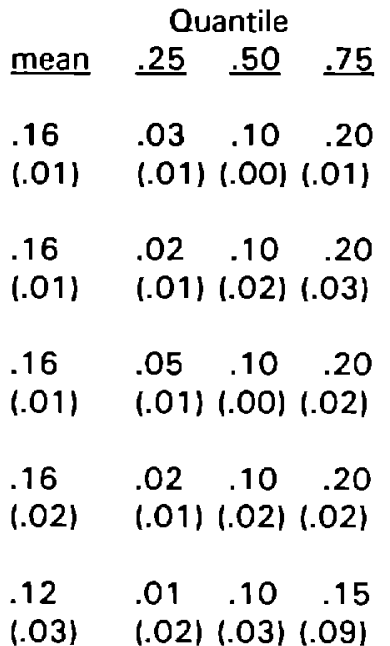

$\begin{array}{llll}.20 & .02 & .10 & .30\end{array}$

\begin{tabular}{|c|c|c|c|}
\hline & \multicolumn{3}{|c|}{ Quantile } \\
\hline mean & .25 & .50 & .75 \\
\hline $\begin{array}{l}.16 \\
(.01)\end{array}$ & $\begin{array}{l}.00 \\
1.00\end{array}$ & $\begin{array}{c}.05 \\
(.00)\end{array}$ & $\begin{array}{r}.20 \\
1.04\end{array}$ \\
\hline $\begin{array}{l}.17 \\
(.02)\end{array}$ & $\begin{array}{l}.00 \\
1.00\end{array}$ & $\begin{array}{l}.05 \\
(.00)\end{array}$ & $\begin{array}{r}.20 \\
(.04)\end{array}$ \\
\hline $\begin{array}{l}.16 \\
(.02)\end{array}$ & $\begin{array}{l}.00 \\
(.00)\end{array}$ & $\begin{array}{c}.05 \\
(.00)\end{array}$ & $\begin{array}{r}.20 \\
1.02\end{array}$ \\
\hline $\begin{array}{l}.13 \\
(.02)\end{array}$ & $\begin{array}{l}.00 \\
(.00)\end{array}$ & $\begin{array}{l}.02 \\
(.01)\end{array}$ & .1 \\
\hline $\begin{array}{l}.17 \\
(.05)\end{array}$ & $\begin{array}{l}.00 \\
1.001\end{array}$ & .00 & 19 \\
\hline
\end{tabular}

(.02) (.01) (.02) (.05)

$\begin{array}{llll}.17 & .05 & .10 & .20\end{array}$

(.01) $(.01)(.01)(.03)$

$\begin{array}{llll}.12 & .02 & .05 & .15\end{array}$

(.01) (.01) (.02) (.04)

$\begin{array}{llll}.14 & .02 & .10 & .20\end{array}$

(.01) (.01) (.01) (.00)

$\begin{array}{llll}.33 & .05 & .30 & .50\end{array}$

(.04) (.04) (.10) (.05)

$\begin{array}{llll}.16 & .03 & .10 & .20\end{array}$

(.01) $(.01)(.00)(.01)$ $\begin{array}{llll}.08 & .00 & .00 & .10\end{array}$

(.01) $\quad(.00)(.01)(.00)$
Job Loss

$\begin{array}{llll}.20 & .00 & .05 & .30\end{array}$

(.02) $(.00)(.01)(.10)$

$\begin{array}{llll}.15 & .00 & .05 & .20\end{array}$

$(.01) \quad(.00)(.00)(.04)$

$\begin{array}{llll}.15 & .00 & .05 & .10\end{array}$

(.01) $(.00)(.00)(.02)$

$\begin{array}{llll}.15 & .00 & .05 & .10\end{array}$

(.01) $\quad(.00)(.00)(.03)$

$\begin{array}{llll}.24 & .01 & .20 & .50\end{array}$

$(.03) \quad(.07)(.05)(.07)$

$\begin{array}{llll}.14 & .00 & .05 & .15\end{array}$

(.01) $(.00)(.01)(.04)$ 
Table 3: Population Means and Quantiles of the Subjective Probabilities (cont.)

\begin{tabular}{|c|c|c|c|c|c|c|c|c|c|c|c|c|}
\hline & & & antile & & & & antile & & & Qua & ntile & \\
\hline & mean & .25 & .50 & .75 & mean & .25 & .50 & .75 & mean & .25 & .50 & .75 \\
\hline Female & $\begin{array}{l}.15 \\
(.01)\end{array}$ & $\begin{array}{l}.00 \\
1.001\end{array}$ & $\begin{array}{l}.02 \\
(.01)\end{array}$ & $\begin{array}{l}.20 \\
(.01)\end{array}$ & $\begin{array}{l}.18 \\
(.01)\end{array}$ & $\begin{array}{l}.02 \\
1.011\end{array}$ & $\begin{array}{l}.10 \\
(.00)\end{array}$ & $\begin{array}{r}.25 \\
(.03)\end{array}$ & $\begin{array}{l}.20 \\
(.01)\end{array}$ & $\begin{array}{l}.00 \\
1.00)\end{array}$ & $\begin{array}{l}.05 \\
(.00)\end{array}$ & $\begin{array}{r}.25 \\
(.04)\end{array}$ \\
\hline Age $18-34$ & $\begin{array}{l}.17 \\
(.01)\end{array}$ & $\begin{array}{l}.00 \\
1.00)\end{array}$ & $\begin{array}{l}.05 \\
(.02)\end{array}$ & $\begin{array}{l}.20 \\
(.04)\end{array}$ & $\begin{array}{l}.18 \\
1.011\end{array}$ & $\begin{array}{l}.05 \\
1.011\end{array}$ & $\begin{array}{l}.10 \\
(.00)\end{array}$ & $\begin{array}{r}.25 \\
(.04)\end{array}$ & $\begin{array}{l}.24 \\
(.02)\end{array}$ & $\begin{array}{l}.00 \\
(.01)\end{array}$ & $\begin{array}{l}.05 \\
(.01)\end{array}$ & $\begin{array}{r}.50 \\
(.10)\end{array}$ \\
\hline Age $35-49$ & $\begin{array}{l}.15 \\
(.01)\end{array}$ & $\begin{array}{l}.00 \\
1.001\end{array}$ & $\begin{array}{l}.01 \\
(.02)\end{array}$ & $\begin{array}{l}.20 \\
(.02)\end{array}$ & $\begin{array}{l}.18 \\
1.011\end{array}$ & $\begin{array}{l}.03 \\
1.011\end{array}$ & $\begin{array}{l}.10 \\
(.00)\end{array}$ & $\begin{array}{r}.25 \\
(.03)\end{array}$ & $\begin{array}{l}.20 \\
1.021\end{array}$ & $\begin{array}{l}.00 \\
1.00)\end{array}$ & $\begin{array}{l}.05 \\
(.00)\end{array}$ & $\begin{array}{r}.25 \\
(.05)\end{array}$ \\
\hline Age $50-64$ & $\begin{array}{l}.13 \\
(.02)\end{array}$ & $\begin{array}{l}.00 \\
(.00)\end{array}$ & $\begin{array}{l}.00 \\
(.00)\end{array}$ & $\begin{array}{l}.10 \\
(.02)\end{array}$ & $\begin{array}{l}.18 \\
(.02)\end{array}$ & $\begin{array}{l}.01 \\
(.01)\end{array}$ & $\begin{array}{c}.05 \\
(.02)\end{array}$ & $\begin{array}{r}.30 \\
(.07)\end{array}$ & $\begin{array}{l}.14 \\
(.02)\end{array}$ & $\begin{array}{l}.00 \\
1.001\end{array}$ & $\begin{array}{c}.02 \\
(.01)\end{array}$ & $\begin{array}{r}.10 \\
(.04)\end{array}$ \\
\hline Age $65+$ & $\begin{array}{l}.09 \\
(.03)\end{array}$ & $\begin{array}{l}.00 \\
1.001\end{array}$ & $\begin{array}{l}.00 \\
(.02)\end{array}$ & $\begin{array}{l}.10 \\
(.05)\end{array}$ & $\begin{array}{l}.15 \\
(.03)\end{array}$ & $\begin{array}{l}.00 \\
(.02)\end{array}$ & $\begin{array}{c}.05 \\
(.03)\end{array}$ & $\begin{array}{r}.25 \\
(.10)\end{array}$ & $\begin{array}{l}.20 \\
(.06)\end{array}$ & $\begin{array}{l}.00 \\
1.001\end{array}$ & $\begin{array}{r}.01 \\
(.05)\end{array}$ & $\begin{array}{r}.50 \\
1.221\end{array}$ \\
\hline No College & $\begin{array}{l}.18 \\
(.02)\end{array}$ & $\begin{array}{l}.00 \\
1.001\end{array}$ & $\begin{array}{l}.05 \\
(.02)\end{array}$ & $\begin{array}{l}.20 \\
(.10)\end{array}$ & $\begin{array}{l}.18 \\
(.02)\end{array}$ & $\begin{array}{l}.02 \\
(.01)\end{array}$ & $\begin{array}{l}.10 \\
(.02)\end{array}$ & $\begin{array}{l}.25 \\
(.07)\end{array}$ & $\begin{array}{l}.23 \\
(.03)\end{array}$ & $\begin{array}{l}.00 \\
(.00)\end{array}$ & $\begin{array}{l}.05 \\
(.01)\end{array}$ & $\begin{array}{r}.30 \\
(.11)\end{array}$ \\
\hline Some College & $\begin{array}{l}.16 \\
(.01)\end{array}$ & $\begin{array}{l}.00 \\
(.00)\end{array}$ & $\begin{array}{l}.02 \\
(.01)\end{array}$ & $\begin{array}{l}.20 \\
(.02)\end{array}$ & $\begin{array}{l}.19 \\
(.01)\end{array}$ & $\begin{array}{l}.05 \\
(.01)\end{array}$ & $\begin{array}{l}.10 \\
(.00)\end{array}$ & $\begin{array}{r}.30 \\
(.03)\end{array}$ & $\begin{array}{l}.20 \\
(.02)\end{array}$ & $\begin{array}{l}.00 \\
(.00)\end{array}$ & $\begin{array}{l}.05 \\
1.001\end{array}$ & $\begin{array}{r}.20 \\
(.06)\end{array}$ \\
\hline Bachelor Degree & $\begin{array}{l}.11 \\
(.01)\end{array}$ & $\begin{array}{l}.00 \\
(.00)\end{array}$ & $\begin{array}{l}.00 \\
(.00)\end{array}$ & $\begin{array}{l}.10 \\
(.03)\end{array}$ & $\begin{array}{l}.16 \\
(.01)\end{array}$ & $\begin{array}{l}.03 \\
(.01)\end{array}$ & $\begin{array}{l}.10 \\
(.02)\end{array}$ & $\begin{array}{r}.20 \\
1.031\end{array}$ & $\begin{array}{l}.18 \\
(.02)\end{array}$ & $\begin{array}{l}.00 \\
(.00)\end{array}$ & $\begin{array}{l}.05 \\
1.001\end{array}$ & $\begin{array}{r}.20 \\
(.06)\end{array}$ \\
\hline White & $\begin{array}{l}.15 \\
(.01)\end{array}$ & $\begin{array}{l}.00 \\
1.001\end{array}$ & $\begin{array}{l}.02 \\
(.01)\end{array}$ & $\begin{array}{l}.20 \\
(.02)\end{array}$ & $\begin{array}{l}.18 \\
1.01)\end{array}$ & $\begin{array}{l}.02 \\
(.01)\end{array}$ & $\begin{array}{l}.10 \\
(.00)\end{array}$ & $\begin{array}{r}.25 \\
(.02)\end{array}$ & $\begin{array}{l}.19 \\
(.01)\end{array}$ & $\begin{array}{l}.00 \\
(.00)\end{array}$ & $\begin{array}{l}.05 \\
1.001\end{array}$ & $\begin{array}{r}.20 \\
(.02)\end{array}$ \\
\hline Black & $\begin{array}{l}.19 \\
(.03)\end{array}$ & $\begin{array}{l}.00 \\
1.00\end{array}$ & $\begin{array}{l}.02 \\
(.03)\end{array}$ & $\begin{array}{l}.30 \\
(.13)\end{array}$ & $\begin{array}{l}.20 \\
(.03)\end{array}$ & $\begin{array}{l}.05 \\
(.03)\end{array}$ & $\begin{array}{l}.10 \\
(.04)\end{array}$ & $\begin{array}{r}.40 \\
(.12)\end{array}$ & $\begin{array}{l}.25 \\
(.03)\end{array}$ & $\begin{array}{l}.02 \\
(.01)\end{array}$ & $\begin{array}{l}.10 \\
(.05)\end{array}$ & $\begin{array}{r}.50 \\
(.08)\end{array}$ \\
\hline $\begin{array}{l}\text { Employed } \\
\text { w/Health Ins. }\end{array}$ & $\begin{array}{l}.10 \\
(.01)\end{array}$ & $\begin{array}{l}.00 \\
(.00)\end{array}$ & $\begin{array}{l}.00 \\
(.00)\end{array}$ & $\begin{array}{l}.10 \\
(.01)\end{array}$ & $\begin{array}{l}.18 \\
(.01)\end{array}$ & $\begin{array}{l}.03 \\
(.01)\end{array}$ & $\begin{array}{c}.10 \\
(.00)\end{array}$ & $\begin{array}{r}.25 \\
(.02)\end{array}$ & $\begin{array}{l}.15 \\
(.01)\end{array}$ & $\begin{array}{l}.00 \\
(.00)\end{array}$ & $\begin{array}{c}.05 \\
(.01)\end{array}$ & $\begin{array}{r}.20 \\
(.02)\end{array}$ \\
\hline
\end{tabular}

Job Loss

Job Loss$$
\begin{array}{llll}
.15 & .00 & .02 & .20 \\
1.011 & (.001 & (.01)(.01)
\end{array}
$$$$
\begin{array}{llll}
.17 & .00 & .05 & .20 \\
(.01) & 1.001 & (.02) & (.04)
\end{array}
$$$$
\begin{array}{llll}
.15 & .00 & .01 & .20 \\
(.01) & 1.001 & (.02) & (.02)
\end{array}
$$$$
\begin{array}{llll}
.13 & .00 \quad .00 \quad .10 \\
1.021 & 1.001 & 1.00 & 1.021
\end{array}
$$$$
\begin{array}{llll}
.09 & .00 & .00 & .10 \\
(.03) & (.00) & (.02) & (.05)
\end{array}
$$$$
\begin{array}{llll}
.18 & .00 & .05 & .20 \\
1.02) & (.00) & (.02) & (.10)
\end{array}
$$$$
\begin{array}{llll}
.16 & .00 & .02 & .20 \\
(.01) & (.00) & (.01) & (.02)
\end{array}
$$$$
\text { (.01) } \quad(.00)(.00)(.03)
$$

$(.00)(.00)(.01)$
$(.01) \quad(.01)(.00)(.02)$
$(.01) \quad(.00)(.01)(.02)$ No Health Insurance Victim of Burglary

\begin{abstract}
Table 3: Population Means and Quantiles of the Subjective Probabilities (cont.)
\end{abstract}


Table 4: Concentration of Insecurity

\begin{tabular}{|c|c|c|c|c|}
\hline & $\begin{array}{l}\text { Relatively } \\
\text { Secure }\end{array}$ & Intermediate & $\begin{array}{r}\text { Relatively } \\
\text { Insecure }\end{array}$ & $\begin{array}{l}\text { Highly } \\
\text { Insecure }\end{array}$ \\
\hline Male & $\begin{array}{l}.16 \\
(.01)\end{array}$ & $\begin{array}{l}.70 \\
(.01)\end{array}$ & $\begin{array}{l}.14 \\
(.01)\end{array}$ & $\begin{array}{l}.04 \\
(.01)\end{array}$ \\
\hline Age $18-34$ & $\begin{array}{l}.16 \\
(.02)\end{array}$ & $\begin{array}{l}.70 \\
(.02)\end{array}$ & $\begin{array}{l}.14 \\
(.02)\end{array}$ & $\begin{array}{l}.05 \\
(.01)\end{array}$ \\
\hline Age $35-49$ & $\begin{array}{l}.15 \\
(.02)\end{array}$ & $\begin{array}{l}.69 \\
(.02)\end{array}$ & $\begin{array}{l}.16 \\
(.02)\end{array}$ & $\begin{array}{l}.04 \\
1.01)\end{array}$ \\
\hline Age 50-64 & $\begin{array}{l}.20 \\
(.03)\end{array}$ & $\begin{array}{l}.71 \\
(.03)\end{array}$ & $\begin{array}{l}.09 \\
(.02)\end{array}$ & $\begin{array}{l}.02 \\
1.011\end{array}$ \\
\hline Age 65 or more & $\begin{array}{l}.28 \\
(.08)\end{array}$ & $\begin{array}{l}.56 \\
1.09)\end{array}$ & $\begin{array}{l}.16 \\
(.07)\end{array}$ & $\begin{array}{l}.00 \\
1.001\end{array}$ \\
\hline No College & $\begin{array}{l}.16 \\
(.02)\end{array}$ & $\begin{array}{l}.65 \\
(.03)\end{array}$ & $\begin{array}{l}.19 \\
(.03)\end{array}$ & $\begin{array}{l}.07 \\
(.02)\end{array}$ \\
\hline Some College & $\begin{array}{l}.15 \\
(.02)\end{array}$ & $\begin{array}{l}.68 \\
(.02)\end{array}$ & $\begin{array}{l}.17 \\
1.021\end{array}$ & $\begin{array}{l}.04 \\
(.02)\end{array}$ \\
\hline Bachelor Degree & $\begin{array}{l}.18 \\
(.02)\end{array}$ & $\begin{array}{l}.75 \\
. .02)\end{array}$ & $\begin{array}{l}.07 \\
1.011\end{array}$ & $\begin{array}{l}.02 \\
(.01)\end{array}$ \\
\hline White & $\begin{array}{l}.17 \\
(.01)\end{array}$ & $\begin{array}{l}.71 \\
(.02)\end{array}$ & $\begin{array}{l}.12 \\
(.01)\end{array}$ & $\begin{array}{l}.02 \\
(.00)\end{array}$ \\
\hline Black & $\begin{array}{l}.08 \\
(.03)\end{array}$ & $\begin{array}{l}.56 \\
(.06)\end{array}$ & $\begin{array}{l}.36 \\
(.06)\end{array}$ & $\begin{array}{l}.18 \\
(.05)\end{array}$ \\
\hline $\begin{array}{l}\text { Employed with } \\
\text { Health Insurance }\end{array}$ & $\begin{array}{l}.19 \\
(.01)\end{array}$ & $\begin{array}{l}.68 \\
(.02)\end{array}$ & $\begin{array}{l}.13 \\
(.01)\end{array}$ & $\begin{array}{l}.03 \\
(.01)\end{array}$ \\
\hline
\end{tabular}


Table 4: Concentration of Insecurity (continued)

\begin{tabular}{|c|c|c|c|c|}
\hline & $\begin{array}{l}\text { Relatively } \\
\text { Secure }\end{array}$ & Intermediate & $\begin{array}{l}\text { Relatively } \\
\text { Insecure }\end{array}$ & $\begin{array}{l}\text { Highly } \\
\text { Insecure }\end{array}$ \\
\hline Female & $\begin{array}{l}.16 \\
(.011)\end{array}$ & $\begin{array}{l}.71 \\
(.01)\end{array}$ & $\begin{array}{l}.13 \\
(.01)\end{array}$ & $\begin{array}{l}.03 \\
(.01)\end{array}$ \\
\hline Age 18-34 & $\begin{array}{l}.13 \\
(.02)\end{array}$ & $\begin{array}{l}.74 \\
(.02)\end{array}$ & $\begin{array}{l}.14 \\
(.02)\end{array}$ & $\begin{array}{l}.04 \\
(.01)\end{array}$ \\
\hline Age $35-49$ & $\begin{array}{l}.14 \\
(.02)\end{array}$ & $\begin{array}{l}.72 \\
(.02)\end{array}$ & $\begin{array}{l}.14 \\
(.02)\end{array}$ & $\begin{array}{l}.03 \\
(.01)\end{array}$ \\
\hline Age 50-64 & $\begin{array}{l}.27 \\
(.03)\end{array}$ & $\begin{array}{l}.64 \\
(.04)\end{array}$ & $\begin{array}{l}.09 \\
1.021\end{array}$ & $\begin{array}{l}.02 \\
(.01)\end{array}$ \\
\hline Age 65 or more & $\begin{array}{l}.28 \\
(.07)\end{array}$ & $\begin{array}{l}.60 \\
(.08)\end{array}$ & $\begin{array}{l}.12 \\
1.051\end{array}$ & $\begin{array}{l}.03 \\
(.03)\end{array}$ \\
\hline No College & $\begin{array}{l}.20 \\
(.03)\end{array}$ & $\begin{array}{l}.64 \\
(.03)\end{array}$ & $\begin{array}{l}.16 \\
(.02)\end{array}$ & $\begin{array}{l}.05 \\
(.01)\end{array}$ \\
\hline Some College & $\begin{array}{l}.13 \\
(.02)\end{array}$ & $\begin{array}{l}.74 \\
(.02)\end{array}$ & $\begin{array}{l}.13 \\
(.02)\end{array}$ & $\begin{array}{l}.03 \\
(.01)\end{array}$ \\
\hline Bachelor Degree & $\begin{array}{l}.18 \\
(.02)\end{array}$ & $\begin{array}{l}.72 \\
(.03)\end{array}$ & $\begin{array}{l}.10 \\
(.02)\end{array}$ & $\begin{array}{l}.02 \\
(.01)\end{array}$ \\
\hline White & $\begin{array}{l}.16 \\
(.01)\end{array}$ & $\begin{array}{l}.71 \\
1.021\end{array}$ & $\begin{array}{l}.12 \\
(.01)\end{array}$ & $\begin{array}{l}.03 \\
(.01)\end{array}$ \\
\hline Black & $\begin{array}{l}.20 \\
1.04)\end{array}$ & $\begin{array}{l}.62 \\
1.051\end{array}$ & $\begin{array}{l}.18 \\
(.04)\end{array}$ & $\begin{array}{l}.06 \\
1.03)\end{array}$ \\
\hline $\begin{array}{l}\text { Employed with } \\
\text { Health Insurance }\end{array}$ & $\begin{array}{l}.18 \\
(.01)\end{array}$ & $\begin{array}{l}.71 \\
(.02)\end{array}$ & $\begin{array}{l}.11 \\
(.01)\end{array}$ & $\begin{array}{l}.02 \\
(.01)\end{array}$ \\
\hline
\end{tabular}

standard errors in parentheses 
Table 5: Trends in Risk Perceptions

A. Means and Quantiles of the Subjective Probabilities

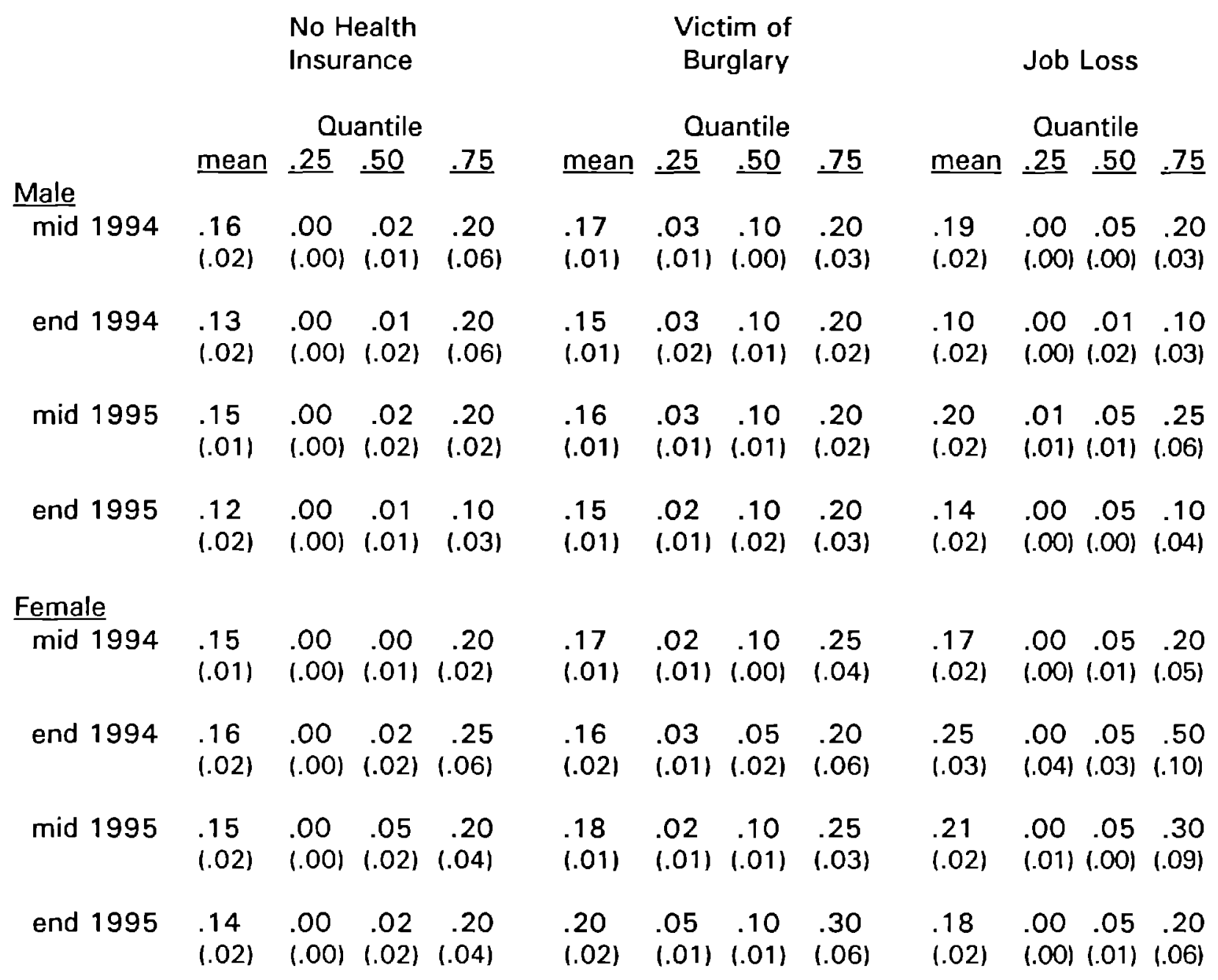


Table 5: Trends in Risk Perceptions (continued)

B. Concentration of Insecurity

\begin{tabular}{|c|c|c|c|c|}
\hline & $\begin{array}{l}\text { Relatively } \\
\text { Secure }\end{array}$ & Intermediate & $\begin{array}{l}\text { Relatively } \\
\text { Insecure }\end{array}$ & $\begin{array}{l}\text { Highly } \\
\text { Insecure }\end{array}$ \\
\hline \multicolumn{5}{|l|}{ Male } \\
\hline mid 1994 & $\begin{array}{l}.17 \\
(.02)\end{array}$ & $\begin{array}{l}.66 \\
(.03)\end{array}$ & $\begin{array}{l}.17 \\
(.02)\end{array}$ & $\begin{array}{l}.06 \\
(.01)\end{array}$ \\
\hline end 1994 & $\begin{array}{l}.18 \\
(.03)\end{array}$ & $\begin{array}{l}.70 \\
(.04)\end{array}$ & $\begin{array}{l}.12 \\
(.03)\end{array}$ & $\begin{array}{l}.03 \\
(.01)\end{array}$ \\
\hline mid 1995 & $\begin{array}{l}.13 \\
(.02)\end{array}$ & $\begin{array}{l}.71 \\
(.03)\end{array}$ & $\begin{array}{l}.16 \\
(.02)\end{array}$ & $\begin{array}{l}.04 \\
(.01)\end{array}$ \\
\hline end 1995 & $\begin{array}{l}.17 \\
(.02)\end{array}$ & $\begin{array}{l}.72 \\
(.03)\end{array}$ & $\begin{array}{l}.11 \\
(.02)\end{array}$ & $\begin{array}{l}.03 \\
(.01)\end{array}$ \\
\hline \multicolumn{5}{|l|}{ Female } \\
\hline mid 1994 & $\begin{array}{l}.16 \\
(.02)\end{array}$ & $\begin{array}{l}.71 \\
(.02)\end{array}$ & $\begin{array}{l}.13 \\
(.02)\end{array}$ & $\begin{array}{l}.03 \\
(.01)\end{array}$ \\
\hline end 1994 & $\begin{array}{l}.18 \\
(.03)\end{array}$ & $\begin{array}{l}.71 \\
(.03)\end{array}$ & $\begin{array}{l}.11 \\
(.02)\end{array}$ & $\begin{array}{l}.05 \\
(.02)\end{array}$ \\
\hline mid 1995 & $\begin{array}{l}.15 \\
(.02)\end{array}$ & $\begin{array}{l}.72 \\
(.03)\end{array}$ & $\begin{array}{l}.13 \\
(.02)\end{array}$ & $\begin{array}{l}.04 \\
(.01)\end{array}$ \\
\hline end 1995 & $\begin{array}{l}.14 \\
(.02)\end{array}$ & $\begin{array}{l}.71 \\
(.03)\end{array}$ & $\begin{array}{l}.15 \\
(.02)\end{array}$ & $\begin{array}{l}.02 \\
(.01)\end{array}$ \\
\hline
\end{tabular}

standard errors in parentheses. 
Table 6. Expectations in 1994 and Realizations in 1995

\begin{tabular}{|c|c|c|c|c|c|c|}
\hline & $\begin{array}{l}\text { No H } \\
\text { Insura }\end{array}$ & & $\begin{array}{l}\text { Victi } \\
\text { Burg }\end{array}$ & & Jot & Loss \\
\hline & Exp & Real & Exp & Real & Exp & Real \\
\hline Male & .15 & .15 & .16 & .05 & .15 & .18 \\
\hline & $(.01)$ & $(.02)$ & $(.01)$ & $(.01)$ & $(.011)$ & $(.02)$ \\
\hline Age 18-34 & .18 & .23 & .16 & .09 & .15 & .29 \\
\hline & $(.02)$ & $(.03)$ & $(.01)$ & $(.02)$ & $(.02)$ & (.03) \\
\hline Age $35-49$ & .14 & .14 & .16 & .03 & .15 & .14 \\
\hline & $(.02)$ & $(.02)$ & $(.01)$ & $(.01)$ & $(.02)$ & $(.02)$ \\
\hline Age $50-64$ & .10 & .03 & .16 & .02 & .12 & .07 \\
\hline & $(.02)$ & $(.02)$ & $(.03)$ & (.02) & (.03) & $(.03)$ \\
\hline Age $65+$ & .09 & .00 & .14 & .03 & .14 & .09 \\
\hline & $(.07)$ & $(.00)$ & $(.05)$ & $(.04)$ & $(.07)$ & $(.07)$ \\
\hline No College & .20 & .30 & .23 & .06 & .18 & .25 \\
\hline & $(.03)$ & $(.04)$ & $(.02)$ & $(.02)$ & $(.02)$ & $(.04)$ \\
\hline Some College & .16 & .16 & .16 & .08 & .14 & .17 \\
\hline & $(.02)$ & $(.03)$ & $(.01)$ & $(.02)$ & $(.02)$ & $(.03)$ \\
\hline Bachelor Deg. & .09 & .06 & .10 & .03 & .13 & .16 \\
\hline & $(.02)$ & $(.02)$ & $(.01)$ & $(.01)$ & $(.02)$ & $(.03)$ \\
\hline White & .14 & .13 & .14 & .04 & .14 & .17 \\
\hline & $(.01)$ & $(.02)$ & $(.01)$ & $(.01)$ & $(.01)$ & $(.02)$ \\
\hline Black & .28 & .15 & .37 & .14 & .24 & .24 \\
\hline & $(.05)$ & $(.07)$ & $(.051$ & $(.06)$ & $(.05)$ & $(.08)$ \\
\hline Female & .16 & .13 & .17 & .03 & .21 & .18 \\
\hline & $(.01)$ & $(.02)$ & $(.01)$ & $(.01)$ & $(.01)$ & $(.02)$ \\
\hline Age 18-34 & .17 & .21 & .17 & .04 & .25 & .27 \\
\hline & $(.02)$ & $(.03)$ & $(.01)$ & $(.02)$ & $(.02)$ & $(.03)$ \\
\hline Age $35-49$ & 16 & .09 & .16 & .03 & .18 & .17 \\
\hline & $(.02)$ & $(.02)$ & $(.01)$ & $(.01)$ & $(.02)$ & $(.03)$ \\
\hline Age $50-64$ & .14 & .05 & .15 & .02 & .17 & .06 \\
\hline & $(.03)$ & $(.02)$ & $(.02)$ & $(.02)$ & $(.03)$ & $(.03)$ \\
\hline Age $65+$ & .02 & .05 & .19 & .00 & .24 & .06 \\
\hline & $(.01)$ & $(.05)$ & $(.05)$ & $(.00)$ & $(.08)$ & $(.05)$ \\
\hline No College & .17 & .17 & .15 & .04 & .23 & .21 \\
\hline & $(.02)$ & $(.04)$ & $(.02)$ & $(.02)$ & $(.03)$ & $(.04)$ \\
\hline Some College & .17 & .16 & .18 & .02 & .21 & .20 \\
\hline & $(.02)$ & $(.02)$ & $(.01)$ & $(.01)$ & $(.02)$ & (.03) \\
\hline Bachelor Deg. & .12 & .05 & .16 & .03 & .19 & .13 \\
\hline & $(.02)$ & $(.02)$ & $(.01)$ & $(.01)$ & $(.02)$ & $(.03)$ \\
\hline White & .15 & .12 & .16 & .03 & .20 & .16 \\
\hline & $(.01)$ & $(.02)$ & $(.011$ & $(.01)$ & $(.02)$ & $(.02)$ \\
\hline Black & .15 & .16 & .22 & .07 & .21 & .33 \\
\hline & $(.03)$ & $(.06)$ & $(.03)$ & (.04) & $(.04)$ & $(.08)$ \\
\hline
\end{tabular}

Standard errors in parentheses 